\title{
Brothers' Keepers, or, The Performance of Mourning: Queer Rituals of Remembrance
}

\section{Peter Dickinson}

Peter Dickinson is Assistant Professor in the Department of English at Simon Fraser University. He is the author of Here is Queer: Nationalisms, Sexualities, and the Literatures of Canada ( $U$ of Toronto P, 1999), and editor of Literatures, Cinemas, Cultures, $a$ special issue of the journal Essays on Canadian Writing (\#76, 2002). Recent essays have appeared or are forthcoming in the Canadian Journal of Film Studies, Modern Drama, Screen, and Biography.

One cannot hold a discourse on the "work of mourning" without taking part in it, without announcing or partaking in death, and first of all in one's own death.

- Jacques Derrida, "By Force of Mourning" (172)

What grief displays ... is the thrall in which our relations with others hold us, in ways that we cannot always recount or explain, in ways that often interrupt the self-conscious account of ourselves we might try to provide, in ways that challenge the very notion of ourselves as autonomous and in control. — Judith Butler, Precarious Life (23)

But it may well be that theatre and performance respond to a psychic need to rehearse for loss, and especially for death.

- Peggy Phelan, Mourning Sex (3)

$\mathrm{I}$

$\mathrm{n}$ her recent book Precarious Life: The Powers of Mourning and Violence, Judith Butler picks up the threads of an argument first sketched in her Antigone's Claim; with some political urgency, especially in the wake of $9 / 11$, she asks how one moves beyond the preoccupation with individual human agency implicit in the question, "What makes for a grievable life?," to a recognition that "[l]oss has 
made a tenuous 'we' of us all" (20; emphasis in original). Acknowledging the terrible and terrifying effects of violence to which sexual and other minorities are routinely subjected, Butler nevertheless posits that

each of us is constituted politically in part by virtue of the social vulnerability of our bodies - as a site of desire and physical vulnerability, as a site of publicity at once assertive and exposed. Loss and vulnerability seem to follow from our being socially constituted bodies, attached to others, at risk of losing those attachments, exposed to others, at risk of violence by virtue of that exposure. (20)

For Butler, then, the more important question becomes how we "transform" or "translate" (to use her words) this loss into a new social ethics and political responsibility, reconfiguring a "model of the human" that accounts for the "you" in "me," and that bears witness to the fact that "I am as much constituted by those I do grieve for as by those whose deaths I disavow, whose nameless and faceless deaths form the melancholic background for my social world" (46, 49).

In this paper, I want to build on Butler's insights here and elsewhere (especially in Antigone's Claim), theorizing the political responsibility and social vulnerability that specifically attend queer rituals of remembrance, as well as some of the masculine-and masculinist-teleologies at the heart of these rituals. How do I grieve for the "man" lost in "human," when it is mostly straight white men who have insisted historically that the latter category is one whose loss as a mode of address must be rehearsed over and over again by all the rest of us? How could I ever call such a man my brother? I explore these and related questions by stressing both the performative and the local applications of a queer theory of mourning. As such, I preface my paper with a brief survey of some spaces of remembrance that in many respects constitute "a landscape of memorialization"1 particular to Vancouver, and that thus serve as the immediate backdrop to my thinking about the larger issues circulating in the

${ }^{1}$ I borrow this phrase from Sharon Rosenberg, who coined it in correspondence with me about my paper. I am extremely grateful to Sharon for the guidance and engaged colloquy she has provided on my work, and on the work of mourning more generally, throughout the course of revising this paper. 


\section{4 / Dickinson}

ensuing pages. In suggesting a "nervous mutating catastrophic reach" to these spaces, and the traumatic events they commemorate, a reach that extends beyond Vancouver and, more importantly, my own immediate experiencing of them, I am structuring my paper along the lines of the model for "performative writing" adopted by Peggy Phelan in her brilliant book Mourning Sex: Performing Public Memories. There, Phelan notes that "[p]erformative writing is an attempt to find a form for "what philosophy wishes all the same to say." She continues:

Rather than describing the performance event in "direct signification," a task that I believe to be impossible and not terrifically interesting, I want this writing to enact the affective force of the performance event again, as it plays itself out in an ongoing temporality made vivid by the psychic process of distortion (repression, fantasy, and the general hubbub of the individual and collective unconscious), and made narrow by the muscular force of political repression in all its mutative violence. The events I disclose here sound differently in the writing of them than in the "experiencing" of them, and it is the urgent call of that difference that I am hoping to amplify here. (11-12)

In the main sections of this paper, then, I am likewise seeking to amplify a difference, focussing on four specifically theatrical performances of mourning in order to note how their respective Vancouver stagings speak both to my own evolving memorialization of the city in which I live, and to a communal history of queer witnessing whose narrative lacunae are precisely what constitute the act of memorialization itself. As Butler puts it, "I tell a story about the relations I choose, only to expose, somewhere along the way, the way I am gripped and undone by these very relations. My narrative falters, as it must" (Precarious Life 23). To this end, I look initially, and most extensively, at the performance work of Margie Gillis and Paula Vogel, women who have both lost biological brothers to AIDS (Christopher Gillis and Carl Vogel, respectively), and who, moreover, have both sought to memorialize their brothers' lives in specific works of art: Gillis in the solo dance piece Torn Roots, Broken Branches and Vogel in the Obie Award-winning play The Baltimore Waltz. The public performance of bereavement by these two women, its ritual repetition, is not, I argue, a narcissistic 
capitulation to grief - as Freud's notion of melancholia would have it-but rather an acknowledgment of community, a symbolic representation of collective struggle in response to an unprecedented social crisis, one that allows for the sharing of loss and the ritualization of remembrance as a precursor to organization and a demand for change.

Here, in theorizing the performance of mourning contra Freud, I will be drawing primarily on the work of two of his more important contemporary interlocutors. In particular, I will be using Butler's influential notion of "gender melancholia," as she has developed and refined the concept over the course of Gender Trouble, Bodies That Matter and, most recently, Antigone's Claim and Precarious Life, and as she has used it to (re)read Freudian (and Lacanian) psychoanalysis in order to demonstrate that homosexual cathexis must precede ego identification and the successful resolution of the Oedipal complex. This will aid in unpacking how performative memorialization overlaps with queer kinship in the texts by Gillis and Vogel. Relatedly, I will also be working from the model for social praxis on offer in Douglas Crimp's important essay "Mourning and Militancy," which takes as its central premise (one that I share) the absolutely necessary connection between mourning/remembrance and activism, especially in the context of the queer community's responses to the AIDS pandemic and decades of unabated anti-gay violence.

I conclude my paper with a very brief analysis of two queer plays which each, in their own way, seek to memorialize-in order to attempt to make sense of-the murder of Matthew Shepard. Terrence McNally's Corpus Christi, an intensely homoerotic retelling of the Biblical passion story, was the subject of bomb threats and picketing when it opened at the Manhattan Theatre Club in the fall of 1998. Following Shepard's murder in October of that year, McNally included a preface in the published version of the play that makes a direct link between the crucifixion of the play's fictional gay protagonist, Joshua, and that of the real-life Shepard. Moisés Kaufman and Tectonic Theater's The Laramie Project is based on interviews with residents of Laramie, Wyoming in the immediate aftermath of Shepard's killing; a dozen or so actors voice the words of more than fifty distraught, angry, uncomprehending, and mediaweary citizens - as well as their own-in an effort to tell the story of this community and, in the words of one resident/character, "say 
it right" (100). The play was recently made into an HBO movie with a who's who of high-profile Hollywood stars. ${ }^{2}$

Both plays are large ensemble pieces that eschew explicit focus on the homosexual victim-as-martyr in favour of a dissection (McNally allegorically, Kaufman documentarily) of the community that produced his homophobic killers. These men, equally our brothers, how do we remember them? I attempt to answer this question by first focussing on a key theatrical convention employed by each play, and then by returning to my opening framing discussion of the specific orientations of queer remembrance in Vancouver via references to local stagings of each play in 2002 (i.e., Hoarse Raven's production of Corpus Christi at Festival House in May and Studio 58's production of The Laramie Project in October). There, I will offer some final Butlerian remarks on mourning and melancholiaand what remains "unspeakable" in each-within the context of the Vancouver queer community's determined efforts to remember Aaron Webster, killed by gay bashers in the same park from which an AIDS Memorial has been barred as unsuitable.

\section{The Landscape of Remembrance}

This last point refers to a particular confluence of the local and the performative that has necessarily influenced the writing and revising of this paper. I am speaking of the completion (in July 2004) and dedication (on 1 December 2004, in a ceremony that coincided with World AIDS Day) of a long-planned, and long-delayed, memorial to British Columbians who have died of AIDS. The site of the memorial is Sunset Beach West, along a grassy and lightly treed knoll at the foot of Broughton Street and Beach Avenue, in the heart of downtown's West End and a short walk east of English Bay and the Stanley Park seawall. Its design consists of a series of 20 steel panels, each close to a metre in width, cut into and winding through the adjacent landscape like a ribbon unfurling in the wind. The memorial's foundation, like Maya Lin's famous Vietnam Veterans' Memorial in Washington, DC, follows the natural grade level of the site, resulting in a height ranging from 0.75-1.5 metres (see figure

${ }^{2}$ The Laramie Project (2002). Directed by Moisés Kaufman. Written by Kaufman and members of the Tectonic Theater Project. Produced by Declan Baldwin. New York: HBO Home Video, 96 min. 
1). Again much like Lin's design, the panels that comprise the Vancouver AIDS Memorial have been laser cut with the names of those who have died from the disease, signifying "their absence from our lives" (Vancouver AIDS Memorial). Small holes have been placed next to each name so that mourners and visitors to the memorial might leave flowers or other tokens of remembrance for lost loved ones. Finally, the following stanza from Spanish-American writer George Santayana's 1896 commemorative verse "To W.P." scrolls above the names, at the top of the memorial:

With you a part of me hath passed away, For in the peopled forest of my mind A tree made leafless by the wintry wind Shall never don again its green array. Chapel and fireside, country road and bay, Have something of their friendliness resigned; Another, if I would, I could not find, And I am grown much older in a day. But yet I treasure in my memory Your gift of charity, your mellow ease, And the dear honor of your amity; For those once mine, my life is rich with these. And I scarce know which part may greater be,What I keep of you, or you rob of me.

(Sonnets and Other Verses 61)

Despite the performance of civic harmony that attended the official ground-breaking ceremony for the memorial in May 2002, and that was likewise featured prominently at the official dedication ceremony in December 2004, public goodwill surrounding the project has not always been very much in evidence. Nor was Sunset Beach, chosen only after an especially arduous and acrimonious two-year public consultation process in June 1998, the site originally proposed for the memorial. Indeed, when the then fledgling AIDS Memorial Committee, working in an ad hoc manner under the auspices of AIDS Vancouver and the Pacific AIDS Resource Centre, first approached the Vancouver Parks Board in 1996 about installing a public monument to the memory of those who have died from AIDS, they proposed a site adjacent Ceperley Park, near the Second Beach 


\section{8 / Dickinson}

entrance to Stanley Park. This proposal was endorsed by the Parks Board at an in-camera meeting in November 1996. However, when word of the planned memorial and its proposed location leaked to the press, there was an immediate public outcry. Ostensibly, debate centred around the lack of public consultation surrounding the process, but various media polls conducted during the period repeatedly suggested that what people most objected to was the choice of Stanley Park as the site for the AIDS Memorial-and precisely because the spot was deemed too public (see Fraser).

Ceperley Park, a highly trafficked part of Stanley Park, popular with both locals and tourists alike, and home to a playground and picnic area frequented by young children and families, was deemed inappropriate for a memorial to AIDS victims. Wasn't it enough that the area was annually turned into the start and end point for the Vancouver AIDS Walk every September? A more discreet location should be found for a permanent memorial. Of course what remained unacknowledged throughout this public discourse on the discourse of publicness was that the woods just north of Ceperley Park are highly trafficked in another way-namely, as a late-night cruising ground for gay, bisexual and otherwise identified men seeking sex

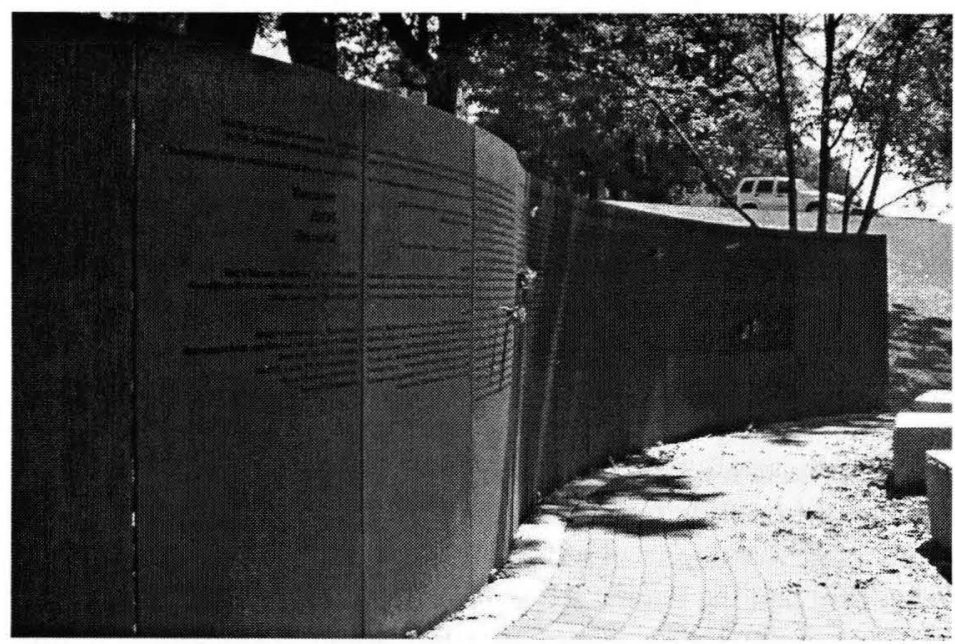

Figure 1: Vancouver AIDS Memorial, Sunset Beach, Vancouver (Photo (C) Peter Dickinson) 
with other men. In the homophobic equation of "gay sex = AIDS" that frequently subtended the debates around erecting a memorial at Ceperley, what remained palpable - even when unspoken-was the feeling that the gay community wished to flaunt itself in broad daylight yet again, that it was somehow rubbing normal Vancouverites' (and, indeed, the world's) noses in a killing field of its own making, one that had best remain hidden away in the dark. Never mind that the killings that go on in this field in Stanley Park under cover of darkness, killings that remain un- or under-memorialized within Vancouver public discourse, have nothing at all to do with the human immunodeficiency virus, and everything to do with "normal" boys who carry baseball bats-a point to which I will return at the end of this essay.

Vancouver's recent history has been particularly vexed on the subject of public memorials. For example, the fallout attending the December 1997 unveiling of artist Beth Alber's Marker of Change memorial in Thornton Park, commemorating the lives of the fourteen women murdered by Marc Lepine at Montreal's École Polytechnique eight years earlier, rehearsed in many ways the same debates around intentionality and appropriateness that have characterized the AIDS Memorial. The conservative local press, led by Vancouver Sun columnist Trevor Lautens, and North Vancouver Reform Party MP Ted White, were particularly aggrieved by the fact that the Women's Monument Project (a feminist collective working out of Capilano College overseeing the design competition, fundraising, and eventual installation of Alber's sculpture), like the AIDS Memorial Society of Vancouver, saw the Marker of Change not merely as commemorative but also as explicitly educative, a way of focussing immediate local attention on the ongoing global phenomenon of male violence against women (see Lautens; Duncan). Clearly the memorial was meant as a feminist indictment of men, the argument went, and, as such, could not be seen as representative of a spirit of shared remembrance in any way. In this regard, critics pointed to the phrase "for all women who have been murdered by men" in the memorial's dedication plaque as unnecessarily provocative.

That same year, Vancouver resident Don Larson angered many in the First Nations community when he spearheaded a campaign to create a monument honouring the memories of the women (many of them Aboriginal sex trade workers) who began disappearing from 
Vancouver's Downtown Eastside (DES) at a statistical rate of approximately two per year in the early 1980 s, a phenomenon that was met with what now seems willful inattention on the part of police and the local media. ${ }^{3}$ Despite the fact that the First Nations community had for several years been staging a public performance of remembrance and a call to action for these same women in the form of a "smudge ceremony," accompanied by demonstrations held each Valentine's Day (see Kelley), Larson-who is white-went ahead and unilaterally commissioned the design of a memorial boulder. The boulder was installed in CRAB (Create a Real Available Beach) Park-3.5 hectares of reclaimed land along the waterfront at the foot of Main Street, in the heart of the DES's skid row (a memorial bench was dedicated separately in March 2000). The fact that the monument's dedicatory inscription appropriates a traditional First Nations' "form of address ['All my relations'] ... used to begin or end a prayer, speech, or story" (Bold et al. 24) only added insult to injury. In the wake of Robert Pickton's arrest and arraignment on charges of murdering fifteen of the more than 60 women currently identified as missing (see note 3 ), and as Aboriginal and nonAboriginal artists alike have begun to exhibit with increasing frequency memorial installations to the murdered and disappeared women, ${ }^{4}$ family members have begun to discuss - and argue aboutplans for a new permanent and official monument.

${ }^{3}$ In their article "'How Might a Women's Monument Be Different?,"' Christine Bold, Ric Knowles, and Belinda Leach discuss in more detail the public debates that greeted both Alber's Marker of Change and Larson's efforts to remember the missing women from Vancouver's DES, situating those debates within the context of a larger project about feminist memorialization in Canada. Despite substantial evidence and ongoing pressure from the local community and relatives, Vancouver police refused throughout the 1980 s and most of the 1990 s to acknowledge a connection between the missing women from the DES, or to entertain the possibility that a serial murderer might be preying upon them. It was only in 2001 that the police, in conjunction with the RCMP, set up a special Missing Women Task Force; a year later, in February 2002, Robert "Willie" Pickton, a 53-year-old pig farmer from Port Coquitlam, was finally arrested in connection with the case. A terrible irony is that Pickton had been in police custody back in 1997 on charges of stabbing a local prostitute; however, the charges were stayed, and Pickton was released (see Joyce; "Vancouver's legacy").

${ }^{4}$ See, for example, Rebecca Belmore's mixed media installations "Vigil" and "The Named and the Unnamed," which were shown in her solo show The Named and the Unnamed at the Morris and Helen Belkin Art Gallery in Vancouver from October-December 2002, before traveling to the Art Gallery of Ontario; see, as well, 
More recently, Vancouver veterans reacted with outrage when, in the summer of 2003, a loose coalition of youthful protestors wishing to focus attention on homelessness, poverty, and City Hall's repeated delays in converting the abandoned Woodward's Building to social housing, set up an impromptu squat at Victory Square, site of the cenotaph commemorating British Columbians who lost their lives in World Wars I and II. The veterans saw the squatters' actions as a desecration and a violation of public memorial space devoted to the preservation of the past; they also worried that the protest would delay plans by the city to renovate and spruce up the memorial site in time for November Remembrance Day activities. For their part, the squatters argued that their occupation of the square constituted a different kind of (re)memorialization, a protest against the city's active forgetting of its spatial present (see Fong). Ironically, when forced by a police injunction to vacate Victory Square, the protesters split their forces, with half decamping to CRAB Park, and the other half to Thornton Park.

\section{"The Protocols of Mourning"}

At the heart of these debates are some fundamentally difficult and necessarily polarizing questions about public memory, memorialization, and mourning: Who gets to publicly remember, for whom, where, in what ways, and how? What constitutes an appropriate (there's that word again) display-psychically, materially-of mourning? When does respectful remembrance cross the line into social activism? And how are all of these rituals further complicated by what Marianne Hirsch and others have called the phenomenon of "postmemory" (see especially Hirsch's Family Frames), in which the "performance" of remembrance via internet sites, television shows, and other media technologies designed to remember for us, produces a constant - though necessarily simulacral and ersatz-condition of reminiscence and retrospection that signals not so much a felt connection with the past (including the very recent past) as a profound disconnection from it? For Andreas Huyssen, this globalized penchant for instant memorialization - in everything from hurried architectural

Kati Campbell's textile installation "67 Shawls," which was shown as part of a group show called Talking Textile (which also featured work by Belmore) at the Richmond Art Gallery from December 2003-January 2004. 


\section{2 / Dickinson}

competitions to rebuild Ground Zero in New York City to more populist expressions of remembrance, such as roadside displays of flowers marking the site of a car crash-has, paradoxically, produced what he calls a "culture of amnesia," whose primary symptom is the "atrophy" of historical consciousness, aided and abetted by a hightech "media world spinning a cocoon of timeless claustrophobia and nightmarish phantasms and simulation," in which there is "nothing to remember, nothing to forget" (Twilight Memories 7, 9). However, as Richard Cavell has recently pointed out, Huyssen's argument is profoundly "normative": "there are good memories and there are bad memories for [Huyssen], and bad memories usually tend to be associated with populist expression-what one might call 'history from below' as opposed to the official or institutional histories most often valorised by the state" ("Histories of Forgetting" 2).

Although Huyssen has since revised his take somewhat in his book Present Pasts, even there his critical perspective "is guided by the conviction that too much of the contemporary memory discourse focuses on the personal" (8), especially with respect to episodes of trauma. Such sentiments issue from the statist view that nations, for example, primarily build public monuments to-and organize museums around - great events and great men. These spatial aids to memory (what Pierre Nora has theorized, in the French context, as les lieux de mémoire; see his three-volume study of the same name), so the theory goes, in turn help citizens remember iconographically, ensuring that, in the present, we will not forget the past, lest we repeat its mistakes. But this somewhat naively holistic and ameliorative view of historical memory as a collective cultural repository from which humanity progresses forward is, it seems to me, undercut by precisely the more populist, impromptu, localized, and, yes, performative forms of memorialization that Huyssen eschews from his analysis. Take, for example, a queer ritual of remembrance such as the Names Project Memorial Quilt, and its relation to how bodies (as opposed to monuments) re-member space, be it the space of a national government capital or the space of history. What the formerly semi-regular unfurling of the quilt on the grounds of the National Mall in Washington, D.C. ${ }^{5}$ demonstrated most vividly was that

5 The Quilt, which now comprises some 45,000 panels, weighs more than 54 tons, and covers approximately $1,270,350$ square feet (or roughly the equivalent of 
recovering a narrative of collective memory need not be at the expense of all of the individual bodies and personal stories subsumed within that narrative; nor must memorialization's pedagogical function be separated from its political one. ${ }^{6}$ Each vibrantly sewn and personalized panel seeks to preserve individual eccentricities and encapsulate the life story of its memorial subject, lest his or her death fade into a roll call of anonymous statistics about AIDS' human toll. At the same time, the display of this individual privation is undertaken in a highly theatrical, ritualized, and intensely public manner: each panel is laid out for viewing in an intensely choreographed manner as the names of persons who have died from the disease are read out by alternating participants at a microphone. Carried out in the shadow of a nation's ultimate folly (the hyperphallic Washington Monument), just a short distance away from the rows of indistinguishable white crosses at Arlington National Cemetery and from the equally white seat of world democracy from which issued the edict "Don't ask, don't tell," such a memorial project is a defiantly personalist resistance of the attempts by governments to muzzle and displace grief through monumentalist abstraction. The Quilt insists not only on telling, but also on showing; it is a performance of mourning that doubles as a political occupation. As Elinor Fuchs notes in a 1993 article originally published in American Theatre (and reprinted in her book The Death of Character), the whole idea of the Quilt,

combining monumentality with patchwork, expresses at once the scale of the leaping world AIDS crisis and its assault on humanist faith in order and social continuity. Pastiche and defiant disunity are by now familiar hallmarks of the postmodernist artwork, but here they are returned to a humanism which insists that this exuberant life not be forgotten. In the way it remembers, the Quilt is more relaxed, more inclusive, more sensual, more human, more theatrical

47 football fields if laid end to end), was last displayed in its entirety in October 1996. While portions of the Quilt continue to tour the U.S. and the world, for obvious logistical reasons there are no immediate plans to assemble and display the whole thing again; see the AIDS Memorial Quilt website at www.aidsquilt.org.

${ }^{6}$ On this point, see especially the essays collected in Roger Simon, Sharon Rosenberg, and Claudia Eppert, eds., Between Hope and Despair: Pedagogy and the Remembrance of Historical Trauma. 


\section{4 / Dickinson}

than anything previously imagined in the protocols of mourning. (196)

I want to link up what Fuchs singles out here as the Quilt's inherent "theatricality," its necessary "imaginativeness," with Huyssen's speculative hand-wringing about the "cultural amnesia" that he sees as a worrisome by-product of such memorial projects. At a physiological level, of course, the cognitive condition of forgetting must in some senses always precede, even prompt, the cognitive condition of remembering. That is, an irony that seems to be lost on Huyssen is that we can only remember something that we have first forgotten. And how do you remember that which official or institutional histories of the sort privileged by Huyssen have refused to record, and thereby literally make impossible to forget? I overstate my case, to be sure, but I do so in order to make an important point about the necessarily performative nature of queer rituals of remembrance and mourning. Phelan puts it this way: "[a]s an art form whose primary function is to meditate on the threshold that heralds between-ness, theatre encourages a specific and intense cathetic response in those who define themselves as liminal tricksters, socially disenfranchised, sexually aberrant, addicted, and otherwise queerly alienated from the law of the father. Queers are queer because we recognize that we have survived our own deaths" (16).

When hate crimes against queers go unreported, when the names of gay men and lesbians killed in Nazi death camps are nowhere to be found at the Holocaust Memorial at Yad Vashem, ${ }^{7}$ when the archiving of gay life - let alone gay death - has been and continues to be so scant and piecemeal, how does one remember? One remembers by sewing a piece of fabric onto another, by staging kissins and die-ins at public institutions in major urban metropolises, by placing flowers and placards and talismans in a fence in Wyoming (for a Matthew Shepard) or along a forest path in Vancouver (for an Aaron Webster), by writing plays and choreographing dances for lost

${ }^{7}$ This is not meant to deny the efforts of other memorializations of the Holocaust, both from within and without the queer community, to record this history of persecution. See, in particular, the permanent special exhibit at the United States Holocaust Memorial Museum in Washington, D.C. on the "Nazi Persecution of Homosexuals, 1933-1945"; and Rob Epstein and Jeffrey Friedman's documentary film Paragraph 175. 
brothers. In the absence of built monuments, queer acts of remembrance, witnessing, and mourning necessarily become ritualized through performance, just as they per force get linked to local manifestations of grassroots activism. Indeed, a key element of the organizational success of groups such as ACT UP, AIDS Action Now, Queer Nation, and Outrage! over the past two decades has been their recognition of the co-extensiveness of activism and memorialization, and their ability to adapt the performance of each to a specific situational context. A march and rally in New York, a charity concert in London, a candlelight vigil in Toronto or Vancouver: at some level, with each event, street theatre segues into social protest, just as the mourning of an individual loss helps to clarify the "fundamental dependency and ethical responsibility" of our participation in a "political community of a complex order" (Butler, Precarious Life 22).

Thus, in much the same way that Fuchs has examined how the Quilt necessarily sunders "mourning's ancient links to church, family, class and state" and "re-imagines a connection between politics and the sacred" (197), I want now, in the remainder of this essay, to turn to an analysis of the post-AIDS rituals of grieving, remembrance, art, and social activism in two other performative contexts: dance and theatre. In so doing, I want to link up Butler's theorizing of the relationship between mourning and (queer) kinship with a notion of vigilant remembrance that is both situationally contingent and relationally binding - if not always politically transformative. Christopher Gillis, Carl Vogel, Matthew Shepard, Russell Henderson, Aaron McKinney, Aaron Webster: how am I connected to these men? Why is it incumbent upon me to remember them? How, to use Butler's language, does the rehearsal of their deaths, or the deaths they caused, both constitute me and the other in me? And how does it undo me (see Precarious Life 22-3)?

\section{Queer Kinship: Gillis and Vogel}

Following the 1993 death of her brother, Christopher, who was himself a member of the Paul Taylor Dance Company in New York, Margie Gillis added two new pieces to her staple of solo dances: Landscape, a stark meditation on impending death choreographed for her by Christopher from his hospital bed, and Torn Roots, Broken Branches, a frenzied outpouring of grief that she herself created. In 


\section{$26 /$ Dickinson}

the first, Gillis enters the stage down right. She wears a simple white shift reminiscent of a hospital gown and is dragging a bare tree branch on the floor behind her. A solitary strip of torn cloth has been tied to one of the branch's outermost limbs, and before the piece is over Gillis will add another. As the haunting sounds of an Edvard Grieg composition rise and fall, Gillis begins her long painful walk across the stage, progressing slowly, in halting and unsure steps. Her movements, normally Duncanesque in their expansiveness, are here tiny and contained and precise. Indeed, Gillis's solidity as a dancer, the generous shape of her arms and legs, makes the frailty of her gestures in this piece even more powerful and poignant; when, in the middle of the stage, she stumbles and falls, for example, we know that something more inevitable and inexorable than mere gravity is weighing her down. Near the end of Landscape, Gillis glances back over her shoulder, measuring the distance she has travelled, trying to bridge the gap between where she has come from and where she is going. The psychological and spiritual isolation that Christopher Gillis has attempted to convey with this piece is encapsulated in this one brief moment and the effect is devastating-knowing this, devastated herself, his sister, Margie, picks up the branch and continues on her journey, exiting the stage upper left.

The image of the broken branch is what links Christopher's vision of his own death with Margie's performance of her mourning. Brother and sister's respective choreographic styles, however, could not be more different. In Torn Roots, Broken Branches, the dull grey backdrop of Landscape is replaced by one that is blood red. The piece begins with Gillis in the middle of the stage, hands covering her face, dressed head to toe in black: black hat, long-sleeved black bodice buttoned to the throat, full-length black skirt-a formal funereal shroud that will serve alternately as a prop and a shield, parts of which Gillis will gradually shed, throughout the next four minutes. To the keening wail of Sinéad O'Connor's “I am Stretched on Your Grave," a contemporary arrangement of a traditional Irish dirge, Gillis performs her own dance of mourning. As the song picks up speed, particularly in the closing fiddle section, so too does Gillis, whirling about in faster and wider circles, shaking her skirts and hair in fierce fury, her pain and anger and guilt registering ever more profoundly, ever more clearly, on her face-in the wild look of her eyes, the tight clench of her jaw. To label the combined effect as 
cathartic does not nearly go far enough in describing what both Gillis and the audience have been through by the end of the piece. (I speak from experience, having attended a dance recital by Gillis in Vancouver in 1994 at which both Landscape and Torn Roots, Broken Branches were performed.) Indeed, as with Gillis's iconic predecessor in the dramatization of sisterly grief, Antigone, cathartic release is arguably replaced by something more akin to empathic identification. And this, to allude to my opening epigraph from Derrida, constitutes the "force" of each sister's mourning, as well as the force of her protest-a point to which I shall shortly return.

Let me speak first, though, to Paula Vogel's The Baltimore Waltz, which, as she states in her "Playwright's Note," was written as a direct result of her brother Carl's death from AIDS in 1988. The published play-text reprints a hilarious and touching letter from brother to sister regarding the former's wishes for his memorial service, and Vogel's dedication reads "To the memory of Carlbecause I cannot sew" (101). The play, which premiered at New York's Circle Repertory Company in 1992 (and received a local Vancouver production the following spring courtesy of Pink Ink Theatre), is set in a Baltimore, Maryland hospital. While sitting in a starkly lit waiting room, "Anna" imagines a final journey to Europe with her brother, "Carl," who is slowly dying in another room from AIDS-related pneumonia. It is this dream voyage that comprises most of the play, and in it Anna, and not Carl, is sick, having contracted Acquired Toilet Disease or ATD, a fatal illness spread through contaminated potty seats that seems to afflict mostly single female elementary school teachers. Having learned from Anna's doctor about the experimental research of one Dr. Todesrocheln, a Viennese urologist, and having packed, upon the instructions of his old university pal, Harry Lime, his childhood stuffed rabbit, Carl whisks his sister off to Europe for what she thinks will be a final fling, but what he hopes will result in a cure.

In a swift progression of 30 short scenes Anna and Carl hop from Paris to Amsterdam to Berlin to Vienna, all the while trailed by a shadowy figure referred to in the text only as the "Third Man," a composite character who has the disconcerting habit of metamorphosizing, depending upon the specific locale, into either a potential lover for Anna or a possible enemy for Carl. In these scenes Vogel skewers every conceivable stereotype and convention, from 
the linguistic trials of American tourists to the new age wisdom of Elizabeth Kubler-Ross:

CARL: Calm down, sweetie. You're angry. It's only natural to be angry. Elizabeth Kubler-Ross says that-

ANNA: What does she know about what it feels like to die?! Elizabeth Kubler-Ross can sit on my face. (114-15)

The production notes for The Baltimore Waltz call for a lavish, wildly varied, and deliberately clichéd musical score. And, as with Gillis's performance, dance becomes the carapace both of a brother's death and a sister's mourning. In the final three scenes, for example, Vogel carefully choreographs the climax and rapid denouement of the play around the hackneyed violin strains of three successive Strauss waltzes. In the first of these scenes, a conscious homage to the climactic confrontation between Orson Welles and Joseph Cotten in the 1949 film version of The Third Man, Carl and his friend-turnednemesis, Harry Lime, "waltz-struggle" for Carl's stuffed rabbit on the Prater ferris wheel in Vienna. Harry eventually gives Carl a final, and presumably fatal, push and "waltzes off with the rabbit" (128). In the next scene, the urine-swilling Dr. Todesrocheln asks a frightened Anna "WO IST DEIN BRUDER?" before transforming before her eyes into the Baltimore doctor from the play's opening scene. Anna, suddenly realizing that she is now "awake," rushes to Carl's bedside, only to find him "stiff beneath a white sheet" (130). To the tempo of "The Emperor Waltz" Anna tries to revive her dead brother, but to no avail. In the play's closing sequence, however, we are briefly transported back to the realm of fantasy. As the stage directions read, "Softly, a Strauss waltz begins. Carl ..., perfectly well, waits for Anna. They waltz off as the lights dim" (132). This final tableau, reminiscent as it is of the scene near the end of Tony Kushner's Angels in America: Millennium Approaches, where Prior is permitted one last dance with Louis (114), ${ }^{8}$ is of course doubly encoded with meaning. The waltz, traditionally a dance of courtship, is here inverted as the

${ }^{8} \mathrm{~A}$ further connection between the two plays is that actor/director Joe Mantello originated the roles of Louis and Carl in the initial New York productions of Angels in America and The Baltimore Waltz. Mantello also directed the New York premiere of Terrence McNally's Corpus Christi, discussed below. 
danse macabre, in which Anna is literally partnered with death in the form of her brother, their rehearsal of a familiar, repetitive, and circular twostep a moving attempt on Anna's-and Vogel's-part to forestall the return to "reality" that Freud, for one, sees as the normative end point of the work of mourning.

In his essay "Mourning and Melancholia," Freud distinguishes between two types of mourning. What he labels so-called "normal" mourning manifests itself initially in individuals as opposition to the abandoning of libidinal attachment to the deceased or lost object, but whose work is eventually completed through first the hypercathecting and then the detachment of "memories and expectations ... bound to the [lost] object," resulting in a return to "reality" (24445). By contrast, the so-called "pathological" condition of mourning, what Freud refers to as "melancholia," arises essentially from a narcissistic prolonging of libidinal attachment, or ego-identification, with the lost object (see 250 and ff.). As Freud pithily summarizes, "In mourning it is the world which has become poor and empty; in melancholia it is the ego itself" (246). ${ }^{9}$

Following the Freudian model, then, Gillis's addition of Landscape and Torn Roots, Broken Branches to her repertoire, her apparently compulsive repetition (to allude to another of Freud's famous theories) of them on stages across the world, suggests that she is performing "melancholia" rather than "mourning." Even the lyrics of O'Connor's song- "So I'm stretched on your grave and will lie there forever/If your hands were in mine, I'd be sure we'd not sever"-are suggestive of deeper-than-"normal" attachment. So too with Vogel. In her "Playwright's Note," she states that she began writing The Baltimore Waltz as a way of exorcising her own personal demons vis-à-vis guilt about not accompanying her brother on his last tour of Europe. But while Freud insists that melancholia "is marked by a determinant which is absent in normal mourning" (250), he also never defines what "normal" signifies in this context (nor even what a return to "reality" might look like). Indeed, as Butler has argued, it is melancholia which is in fact constitutive of normative social relations within Western culture, a process which sees

${ }^{9}$ To be sure, as Butler notes, Freud was not always consistent in his theorizing of the differences between mourning and melancholia. See Butler, Precarious Life, 20-21; and Freud, "The Ego and the Id." 


\section{0 / Dickinson}

heterosexual genders, for example, institutionalize and memorialize themselves precisely through a refusal of mourning, that is, through the renunciation of the loss of homosexual genders as "a possibility of love" (Bodies That Matter 235).

Butler's theorization of heterosexual gender identification as a kind of melancholia, in which unresolved same-sex desire is internalized as a prohibition that precedes the incest taboo, has been articulated in different ways across the body of her work, including most representatively Gender Trouble and Bodies That Matter. ${ }^{10}$ However, it is in Antigone's Claim, via her reading of Sophocles' play (structurally the concluding part of his Oedipus trilogy, but, crucially in terms of chronology of composition, the first part to be written), and its treatment in Western philosophical discourse, that Butler demonstrates most forcefully how gender melancholia has helped structure and hierarchize kinship patterns in our society, patterns whose markers of exclusion only fully emerge in death and the performance of mourning. And, in whose normative constitution we also, per force, witness a perverse negation, or non-consummation of the family romance: as Butler puts it, "Antigone, who concludes the oedipal drama, fails to produce heterosexual closure for that drama" (Antigone's Claim 76). At the same time, the prohibition against incest enacted in Sophocles' play, according to Butler, is really something of a red herring. What is more important is how that prohibition has symbolically come to be memorialized as standing in for other socially taboo, morally denigrated, and juridically invalid relationships, modes of gender expression, sexuality, and ways of being and loving in this world, ways that continue to be placed outside the bounds of the normalized nuclear family and the human, and thus subject to social scrutiny, regulation and policing by the state:

${ }^{10}$ See Butler, Gender Trouble, 63ff; and Bodies That Matter, 235-6 and ff. See, as well, the following comments by Gayle Rubin in "The Traffic in Women": “... the incest taboo presupposes a prior, less articulate taboo on homosexuality. A prohibition against some heterosexual unions assumes a taboo against nonheterosexual unions. Gender is not only an identification with one sex; it also entails that sexual desire be directed toward the other sex. The sexual division of labour is implicated in both aspects of gender-male and female it creates them, and it creates them heterosexual" (180). And this from Monique Wittig: "the straight mind continues to affirm that incest, and not homosexuality, represents its major interdiction. Thus, when thought by the straight mind, homosexuality is nothing but heterosexuality" (The Straight Mind 28). 
When the incest taboo works in this sense to foreclose a love that is not incestuous, what is produced is a shadowy realm of love, a love that persists in spite of its foreclosure in an ontologically suspended mode.... Do we say that families that do not approximate the norm but mirror the norm in some apparently derivative way are poor copies, or do we accept that the ideality of the norm is undone precisely through the complexity of its instantiation? For those relations that are denied legitimacy, or that demand new terms of legitimation, are neither dead nor alive, figuring the nonhuman at the border of the human. And it is not simply that these are relations that cannot be honored, cannot be openly acknowledged, and cannot therefore be publicly grieved, but that these relations involve persons who are also restricted in the very act of grieving, who are denied the power to confer legitimacy on loss. (Antigone's Claim 78-9; emphasis in original)

To put this in more familiar contemporary terms, what if today Antigone were attempting to mourn the death of her common-law husband, a former step-daughter from a second marriage that had ended but with whom she was still close, a gay male friend she cared for throughout a prolonged illness, her lesbian lover? In this respect, the force of Antigone's protest, like Gillis's and Vogel's, comes through the staging of their private sisterly grief in very public acts of ritualized remembrance, acting out, and up, performing the personal as political as a direct intervention against a state-sponsored discourse about who can and cannot be mourned, about what, to use Butler's phrasing, remains unspeakable, and unspeakably violent, about any encounter with difference (see Precarious Life 48-9). As Phelan remarks, Antigone and-lest we forget-Ismene, both equally caught, in their different ways of mourning, between life and death, point "to a different form of theatre sisters might one day invent. Such a theatre would be more precise than Sophocles's or Lacan's about the distinction between desire and love" $(16) .{ }^{11}$

${ }^{11}$ In their remarks on Sophocles's play, both Phelan and Butler are drawing on and revising Lacan's famous reading of Antigone in his Seminar VII. For Lacan, Antigone bridges not only the divide between life and death, but also between the imaginary and the symbolic, her defiance of Creon and the law of the father in death a necessary consequence of her tainted birth. 


\section{2 / Dickinson}

Moreover, as Douglas Crimp has pointed out, "for Freud, [mourning] is a solitary undertaking" (236); at no time does he conceive of it as a shared activity. And it is on this account that I consider the works by Gillis and Vogel to challenge fundamentally the standard Freudian model of mourning. This is also where the concept of performance becomes crucial. For performance, it seems to me, whether we are using the term in a "theatrical" or "theoretical" (i.e. Austinian-Derridean-Butlerian-Sedgwickian speech act) sense, always requires an audience. Gillis's and Vogel's public performance of their bereavement, like Fuchs's description of the public displaying of the Quilt, their invitation to audiences to join the dance, as it were, is not capitulation to the singular oppression of grief, but rather an acknowledgment of community, a symbolic representation of collective struggle in response to an unprecedented social crisis, one that allows for the sharing of loss as a precursor to organization and demand for change. ${ }^{12}$

And yet, as Crimp has also pointed out, while collective public mourning rituals have their own affective and even political force, "they nevertheless often seem, from an activist perspective, indulgent, sentimental, defeatist-a perspective only reinforced ... by media constructions of [both mourners and mourned] as hapless victims" (234). Crimp casts aside Freud's interdiction that "any interference with [mourning is] useless or even harmful" (Freud 244), and argues instead for an active-and activist - channelling of grief and loss into the forceful mobilizing of the tenuous collective social body that AIDS has per force made not just of the queer community, but of us all:

We can then partially revise our sense ... of the incompatibility between mourning and activism and say that, for

12 In this regard, it is important to remember that the dance and theatre communities have been at the forefront of mobilizing in the fight against AIDS: think of the DIFFA Dance and Design Project or Equity Cares/Broadway Fights AIDS in New York; think of Dancers for Life or Theatre Cares Week here in Canada. Likewise, I think that it is also important to note, especially within the context of the argument set forth at the outset to this paper, that I attended and was profoundly moved by local performances of the above works by Vogel and Gillis (in 1993 and 1994, respectively) precisely at the height of my volunteer involvement with the AIDS community in Vancouver. See, as well, in this regard Marita Sturken's Tangled Memories: The Vietnam War, the AIDS Epidemic, and the Politics of Remembering, which likewise discusses Freud's dismissal of "the role of collective mourning" (201) within the context of the "conversations with the dead" enacted through the AIDS Quilt. 
many gay men dealing with AIDS deaths, militancy might arise from conscious conflicts within mourning itself, the consequence, on the one hand, of "inadvisable and even harmful interference" with grief and, on the other, of the impossibility of deciding whether the mourner will share the fate of the mourned. (237)

As I have already intimated, my only revision to Crimp's comments here would be that I think it's important, in true Greek fashion, to extend the "shared fate" of mourning (and the militancy it might inspire) in this context beyond "gay men dealing with AIDS deaths." What the work of Gillis and Vogel teaches is that every remembering self is inextricably connected to the production and circulation of larger patterns of cultural memory; no act of remembrance can occur without a simultaneous act of empathic identification (meaning, in this context, projecting one's consciousness into the subjective experience of another in order to attempt to comprehend that experience). In Torn Roots, Broken Branches and The Baltimore Waltz, a sister uses the language of words and the language of the body to reconfigure time and space, imagining herself into the experience of her brother's death, which must also in some senses be her own-and, just as importantly, our own. In the process, the performance of mourning transforms into a performance of protest. In the words of Jill Dolan, Gillis and Vogel are using "the emotion theater inspires to move people to political action, to desire reconfigured social relations, to want to interact intimately with a local and a global community" (90). This harnessing of emotion to action, or even activism as Dolan notes in the subtitle to her book, is what's key. In this sense, it is important to distinguish empathy from what Kushner has identified as the bugbear of catharsis, which, in a neat little capitalist equation, involves an initial expenditure of emotion for a guaranteed return of transcendence ("Notes" 22). By contrast, empathy implies some sense of relationality on the part of producer and consumer (or actor and spectator), an acknowledgment that both are in the event, that the liveness of theatre creates a space in which we can collectively "engage with the social in physically, materially embodied circumstances" (Dolan 90). SILENCE = DEATH, the ACT UP activist slogan, like the performances of Gillis's dance movements and Vogel's play, gives voice to our rage and anger and profound sense of loss; but its rhetorical power, again like the 


\section{4 / Dickinson}

work of Gillis and Vogel, is ultimately choric rather than ventriloquized, encouraging us, inducing us, moving us, to lend our voices to the clarion call for action. We are all our brothers' keepers; and we could all do with sisters as keenly vigilant in reminding us of this point as Gillis and Vogel.

\section{Melancholic Spectatorship: McNally and Kaufman}

Terrence McNally's Corpus Christi recasts the Biblical passion play as a coming-of-age story, set in the small Texas town of the playwright's birth, with the role of Jesus as an initially socially leprous and later progressively more charismatic gay youth named Joshua, who spreads the gospel of love with his "chosen family" of twelve gay brothers, including his sometime lover Judas. Previewing at the Manhattan Theatre Club in late September 1998, the play, by virtue of its subject matter and not least because of the bomb threats, hate mail and picketing that greeted its premiere, became a proleptic and de facto memorialization of and performative mourning for Matthew Shepard when the latter's beaten body was found tied to a fence outside Laramie, Wyoming six days before the play's official opening on October 13. Lest we not see the connection, the playwright himself makes it explicit for us in the preface to the published version of the play: "Beaten senseless and tied to a splitrail fence in near-zero weather, arms akimbo in a grotesque crucifixion, [Matthew Shepard] died as agonizing a death as another young man who had been tortured and nailed to a wooden cross at a desolate spot outside Jerusalem known as Golgotha some 1,998 years earlier. They died, as they lived, as brothers" (vi).

The play's central theatrical conceit is that it makes explicit the performative scaffolding of such narrative and historical equations by having the actors in the company "assume" their characters' roles on stage in front of the audience. With house lights still up, and while members of the audience are still finding their way to their seats, thirteen male actors, clad identically in white shirts and khaki pants (blue jeans in the production I saw), slowly make their way to the stage as if for a casual rehearsal rather than an actual performance, pausing to chat with one another, greet members of the audience, check the props table, and limber up with various physical and vocal exercises. At a pre-arranged signal, one of the actors steps forward and speaks directly to the audience, announcing that the story he 
and his cast mates are about to tell is an "old and familiar one," one we've "all heard over and over, again and again," but that "bears repeating": "The playwright asks your indulgence, as do we, the actors. There are no tricks up our sleeves. No malice in our hearts. We're glad you're here" (1). We then watch as this same actor, who will shortly assume the role of John the Baptist, calls forth each of his fellow actors in turn, blessing them first by their real names before rebaptizing them by the name of one of Joshua / Jesus' twelve disciples.

On a raked proscenium stage, such as the one at the Manhattan Theatre Club, the effect of this opening would, I imagine, be disconcerting enough. In the intimate confines of Festival House, on Vancouver's Granville Island, where I saw Hoarse Raven Theatre's production of the play in May 2002 (see figure 2), the whole thing felt painfully voyeuristic: a spare studio space devoid of a raised stage, fixed seating, or anything even remotely resembling wings, means that actors and audience are quite literally on top of one another and - as McNally has staged things - wont to bump into each other in queuing to get into the room. Indeed, it left me, at certain moments, longing for the return of theatre's invisible fourth

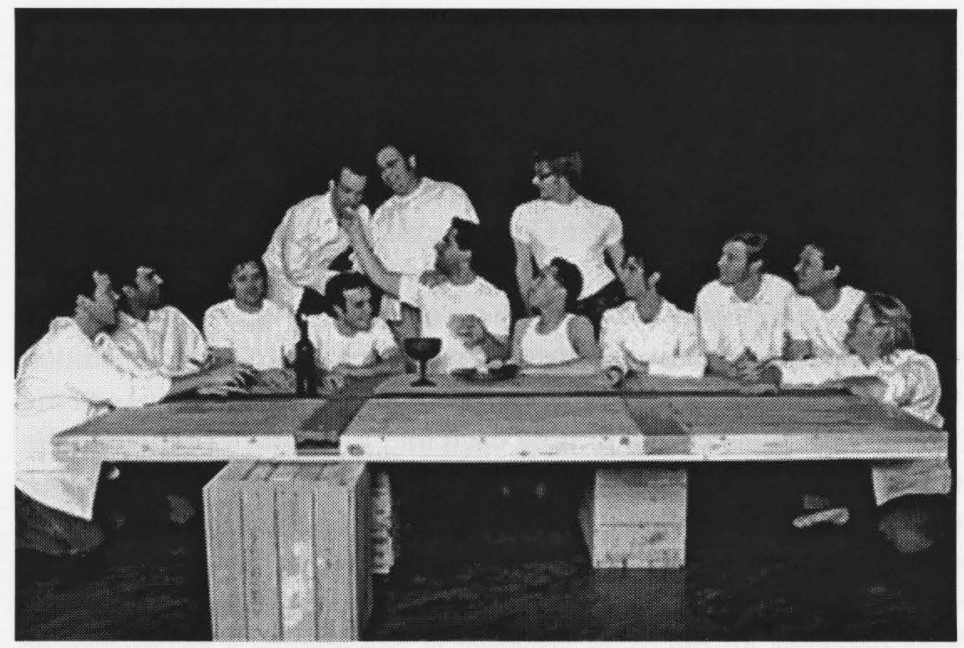

Figure 2: The cast of Hoarse Raven Theatre's Vancouver production of Corpus Christi, May 2002 (Photo @ D David Cooper; reprinted by kind permission) 
wall. This is, of course, precisely the point. In watching this play, as intensely moving and romantic and erotic as so many parts of it are, we are meant to feel uncomfortable, to question whether or not the performance has started, whether it has ended, who precisely is part of the action, whether the actors are playing a version of themselves or their characters or both, and how precisely we in the audience are meant to respond to such alienated and alienating transformations.

Something similar takes place in Moisés Kaufman and Tectonic Theater Project's (TTP) play, The Laramie Project. Famous for its documentary-style approach to historical moments in queer history, the company had previously scored an unexpected international hit with Gross Indecency: The Three Trials of Oscar Wilde. For The Laramie Project, which opened at the Denver Centre Theatre Company in February 2000, members of TTP travelled to the Wyoming town, then recently and unwantedly memorialized via the international media as the redneck locus of Matthew Shepard's brutal murder, in order to conduct interviews with its traumatized residents. A narrator who speaks directly to the audience (as, indeed, do all the "characters" in the play) opens by summarizing the process of its creation:

On November 14, 1999, the members of Tectonic Theater Project traveled to Laramie, Wyoming, and conducted interviews with the people of the town. During the next year, we would return to Laramie several times and conduct over two hundred interviews. The play you are about to see is edited from those interviews, as well as from journal entries by members of the company and other found texts. (Company member Greg Pierotti 5)

The last line of this passage highlights an important feature of The Laramie Project's docudrama—or, more properly, dramatized documentary - narrative aesthetic. That is, the TTP actors, in addition to impersonating on stage the various real-life residents of Laramie whom they interviewed, turning each into a "character" (in both the conventional dramatic sense of playing a part and the broader sense of conveying an individual's distinctive traits or eccentricities through manner of speech, mannerisms, style of dress, etc.), must also deal with the fact that the play likewise turns each of them into a character. This becomes all the more apparent if one attends a production of the play that is being performed by any company or cast other than 
the original TTP ones. Such was the case when I caught a performance of Studio 58's production of the play in October 2002 (see figure 3). A respected actor training program affiliated with Vancouver's Langara College, Studio 58 presented audiences who attended its brilliant staging of The Laramie Project with the spectacle of student-actors playing professional actors playing real people, some of whom, as has been the case with many productions of the play across North America since its premiere, could potentially have been in the audience watching their surrogate-selves on stage on any given night.

The use of the narrator throughout the play to introduce both the speech of the actor-characters and the resident-characters is also integral in orienting — or disorienting - the audience's relationships with the action being portrayed on stage. It is akin to Brechtian quotation, in which lines are spoken not as if they were being spontaneously improvised but rather almost in the manner of reading a report. This distancing effect means that we, in the audience, are compelled not to judge the person doing the speaking but rather the words he/ she speaks, and the larger social attitudes these words betray. In terms

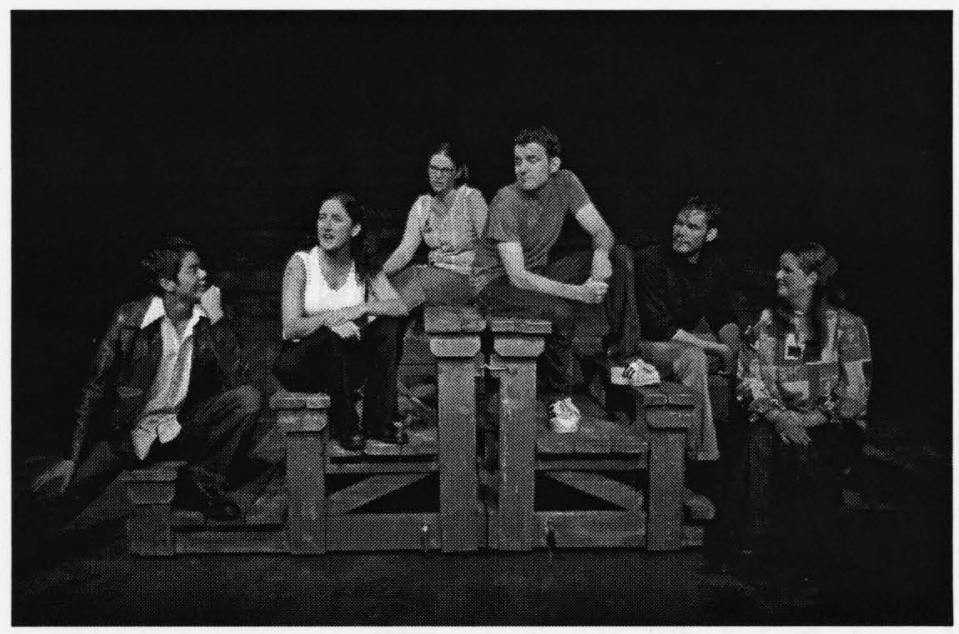

Figure 3: Members of the cast of Studio 58's Vancouver production of The Laramie Project, October 2002; Left to right: Nick Ko, Rebecca Auerbach, Rachel Robillard, Ben Geldreich, Dan Thomas, and Debbie Love (Photo (C) David Cooper; reprinted by kind permission) 


\section{8 / Dickinson}

of the work of memorialization and the performance of mourning operating in The Laramie Project, such a structural device again functions in two ways - on the one hand, disabusing potentially smug audience members of many of the prejudices they may have held towards the residents prior to the performance, and, on the other, dramatizing the important educational process that the actors themselves must go through in confronting their own preconceptions about the individuals they were going to interview or portray.

In short, McNally and Kaufman, following from Brecht's famous theorization of the Alienation-effect's application to the technique of acting, are asking each actor who speaks their words to "invest what he [sic] has to show with a definite gest of showing," whereby gest refers to "the mimetic and gestural expression of the social relationships between people of a given period" $(136,139)$. In so doing, these two queer playwrights are, like Brecht, urging both actors and audiences to adopt "socially critical" attitudes: "In his exposition of the incidents and in his characterization of the person [the actor] tries to bring out those features which come within society's sphere. In this way his performance becomes a discussion (about social conditions) with the audience he is addressing. He prompts the spectator to justify or abolish these conditions according to what class [or gender or sexuality or race or nationality] he belongs to" (Brecht 139). "Look what they did to Him. Look what they did to Him," the actor playing James the Less addresses the audience at the end of Corpus Christi, coming "out of character" and gesturing to the naked body of Joshua crucified on a cross. The actor's Brechtian transposition of his speech into the third person and the past tense here (see Brecht 138) lets neither the actor playing Joshua nor us in the audience off the hook, as it were. Looking in this context becomes precarious-reinforced by the fact that, in the production I saw, all of the other actors exited the studio shortly after this point as the house lights once again came up, leaving the audience to gaze upon the twisted body of the actor playing Joshua for what seemed to be an excruciatingly long time, wondering this time whether the "performance" was over and, if so, whether we should clap or continue to sit in stunned silence. Similarly, in the Epilogue to The Laramie Project, the actor playing TTP company member Greg Pierotti playing gay Laramie resident Jonas Slonaker frames the question "What's come out of this?" (and presumably this applies 
in equal measure to the play we are currently watching / reading and to the murder of Shepard memorialized by it) in terms of a juxtaposition between first and third person, past and present:

Change is not an easy thing, and I don't think people were up to it here. They got what they wanted. Those two boys got what they deserve, and we look good now. Justice has been served. The OK Corral.... The town's cleaned up, and we don't need to talk about it anymore.

You know, it's been a year since Matthew Shepard died, and they haven't passed shit in Wyoming ... at a state level, any town, nobody anywhere, has passed any kind of laws, antidiscrimination laws or hate crime legislation, nobody has passed anything anywhere. (99; second ellipsis in original)

Both speeches force us to interrogate in the present how we have memorialized similar scenes of trauma-in this case, most pertinently, but by no means only, anti-gay and lesbian violenceand our respective identifications or disidentifications with both the "Him" and the "they"-not to mention the "we" and the "you"- of such scenes.

Here I want to link up my all-too cursory redaction of the structural conventions of these two plays to the theoretical ruminations on mourning undertaken in connection with Gillis and Vogel. I suggest that part of the social discussion we in the audience are being asked to engage in by the performers has to do with critically unpacking the complex codes of masculinity operating within the heartland of rural America, and, more specifically, analyzing with whom, in the ritualized violence that all too frequently accompanies the articulation of those codes, we empathize when we mourn. Here, too, I want to bring in the work of JoAnn Wypijewski, who in a 1999 Harper's article entitled "A Boy's Life" has written what I believe to be the most critically astute analysis of Matthew Shepard's murder, wading through "the quasi-religious characterizations of Matthew's passion, death and resurrection as patron saint of hate-crime legislation" to zero in on the "everyday life of hate and hurt and heterosexual culture" that constituted the "psychic terrain" of Aaron McKinney and Russell Henderson, Shepard's murderers (62). Following from Wypijewski, then, it seems to me that the crucial question posed by Corpus Christi and The Laramie 
Project (albeit retrospectively in the case of McNally's play), is why is it that, in the ritual re-membering of this hate-crime (in the media and elsewhere), Shepard, as passive sufferer, automatically becomes representative of all homosexual people, whereas McKinney and Henderson, as violent aggressors, are always discussed in terms of their individual predispositions towards delinquency? Why, in other words, aren't McKinney and Henderson seen, why aren't they remembered, as representative of the attitudes of a larger patriarchalheterosexist culture, a "socially instituted melancholia" that, to adapt Butler, prescribes "how the condemnations under which one lives [e.g. to be gay is to be less than human] turn into repudiations that one performs [e.g. it is alright to kill what is not human]" (Antigone's Claim 80)? ${ }^{13}$ A similar sentiment is expressed toward the end of The Laramie Project by Father Roger Schmit, the Catholic priest whose own attitudes queer TTP writers and cast members Leigh Fondakowski and Greg Pierotti were wont to prejudge upon their initial meeting; Schmit notes:

I think right now our most important teachers must be Russell Henderson and Aaron McKinney. They have to be our teachers. How did you learn? What did we as a society do to teach you that? See, I don't know if many people will let them be their teachers. I think it would be wonderful if the judge said: "In addition to your sentence, you must tell your story, you must tell your story." (89)

Or, as the "Actor Playing Judas" says about his own character at the close of Corpus Christi, "Sometimes I mourn for Judas, too" (80).

\section{Other Brothers}

The Vancouver premieres of Corpus Christi and The Laramie Project in 2002 were all the more compelling because for many of us in the audience the brutal murder of Aaron Webster was still so fresh in our minds. At 2:30 am on Saturday, 17 November 2001, the naked body of 41 year-old Webster was found by his friend Tim Chisholm battered and bleeding in a parking lot near Second Beach in Stanley Park. The victim of a vicious gay bashing, he died a few minutes

${ }^{13}$ That our society largely rejects this kind of memorialization is indicated by the negative reaction, noted above, to the inscription "for all women who have been murdered by men" on Beth Alber's Marker of Change monument. 
later in Chisholm's arms as ambulance paramedics tried to save him. The next day, at an impromptu rally at the corner of Denman and Davie Streets, members of the gay community listened as police and politicians labelled the death a hate crime and vowed to act swiftly to apprehend the perpetrators (see Zacharias). In February 2003, a nineteen-year-old male suspect was finally arrested in connection with the crime. Seventeen at the time of the attack, he could not be identified, and pleaded guilty to manslaughter in juvenile court in July. On 18 December 2003 he was sentenced to two years in custody and one year house arrest, the maximum penalty Judge Valmond Romilly could issue; Romilly explicitly labelled Webster's murder a hate-crime and berated Crown prosecutors for not trying the case within this context. Another juvenile who also pleaded guilty to manslaughter was likewise sentenced to a maximum of three years in custody on 21 April 2004 (see "Second youth"). Ryan Cran and Danny Rao, two adults also charged in connection with the case were tried together in December 2004, with BC Supreme Court Justice Mary Humphries sentencing Cran to six years in jail for manslaughter and acquitting Rao due to lack of credible evidence. The verdicts, together with Humphries' repudiation of Romilly's previous characterization of Webster's murder as a hate crime, outraged the queer community and prompted renewed protests (see Bellett).

As part of the community programming around Studio 58's production of The Laramie Project, Langara College organized a oneday public forum on gay bashing and hate crimes legislation, an issue that has been much in the air in local queer circles since Webster's murder, and especially since Judge Romilly's surprisingly forceful comments. To paraphrase Wypijewski once again, to the extent that "hate-crime laws symbolize a society's values" (74), they can be viewed as a form of cultural memory work, a process of belatedly representing in juridical discourse a hitherto actively forgotten fissure in the social fabric of a community (note, in this regard, how relatively recently anti-gay violence was included under the purview of hate crime legislation in Canada, and how most American states have no legal mechanism to recognize such violence as even constituting a hate crime). This notion of belatedness points, in turn, to the fact that what hate-crime legislation actually memorializes is the crime itself, not the culture of hate and violence that produced the crime in the first place. To this end, Wypijewski notes, with 


\section{2 / Dickinson}

characteristic bluntness, that such legislation "means nothing for life and, because its only practical function is to stiffen penalties, everything for death"; it also means, in the specific context of gayrelated hate crimes, where "it's always the sexuality of the victim that's front and center, not the sexuality of the criminal or the undifferentiated violence he took to extremity," that "straight people are off the hook" $(74,75)$. Similarly, as Judith Butler argues in Excitable Speech, proponents of hate speech regulation, in focussing on the injury such speech causes to the abjectly governed and agentless individual addressee (be it a woman, a queer, or a racial minority), tend to ignore the ways in which their arguments relocate notions of "sovereignty" and "universality" within a speaker, who not only says what he means, but whose utterances are immediately memorialized by others as simultaneously demarcating and overstepping the borders of what is acceptable. Even more pertinently, for Butler, proponents of hate speech laws fail to recognize how the iterability of such speech is to a large measure coextensive with and institutionalized within much official "state speech" (102).

Towards the end of Antigone's Claim, the text that I have been using as my main critical touchstone throughout this paper, and which comes as close as any recent treatise I can think of in articulating a socially relevant theory of queer remembrance and mourning, Butler notes that what remains "unspoken" in Antigone's grief for her brother Polyneices is her shared grief for her "other brother[s]," Eteocles and, not least, Oedipus, both arguably responsible not only for the "crime" of Polyneices' death, but also for the "crime" of Antigone's defiant public mourning of that death. As Butler puts it, "The 'brother' is no singular place for her, though it may be that all her brothers (Oedipus, Polyneices, Eteocles) are condensed at the exposed body of Polyneices, an exposure she seeks to cover, a nakedness she would rather not see or have seen" (79). Likewise, it seems to me that in our vigils for the Aaron Websters and the Matthew Shepards of this world, for the Christopher Gillises and the Carl Vogels, for all our "named and unnamed" queer brothers and sisters lost prematurely to violent death or disease, or simply the violence of heteronormative historiography, we must be as, if not more, vigilant in our remembrance of the un- or underexposed melancholic keepers of that history, our "other" brothers. For, if part 
of what is enacted in queer rituals of remembrance and queer performances of mourning is a speaking of the unspeakable, then it is incumbent upon those of us who undertake such rituals to utter the silence, to outer the active forgetting, to counter the willful amnesia at the heart of heterosexual melancholia: that, to adapt Wypijewski one last time, Aaron Webster and Matthew Shepard, and Brandon Teena and Sakia Gunn, ${ }^{14}$ not to mention the murdered women from the École Polytechnique in Montréal and from the Downtown Eastside in Vancouver, died not because they were queer or feminist or prostitutes, but because their killers were all straight men. And it is this disavowal of brotherly love (of the self, of the same, of the other) at the heart of masculine identity formation that, above all, our culture must mourn.

\section{Works Cited}

The AIDS Memorial Quilt. <www.aidsquilt.org>.

Bellett, Gerry. "Attacker gets six years for role in fatal beating." Vancouver Sun 9 February 2005: B1, B6.

Belmore, Rebecca. The Named and the Unnamed. Morris and Helen Belkin Art Gallery, Vancouver. 4 October-1 Dececmber 2002.

Bold, Christine, Ric Knowles, and Belinda Leach. “"How Might a Feminist Monument Be Different?"' Essays on Canadian Writing 80 (2003): 17-35.

Boys Don't Cry. Dir. Kimberly Pierce. Fox Searchlight, 1999.

The Brandon Teena Story. Dir. Gréta Olafsdôttir and Susan Muska. New Video Group, 1998.

Brecht, Bertolt. "Short Description of a New Technique of Acting which Produces an Alienation Effect." Brecht on Theatre: The

${ }^{14}$ Brandon Teena (aka Teena Brandon), a 21-year-old preoperative transgendered man from Lincoln, Nebraska, was, along with Lisa Lambert and Philip Devine, murdered on New Year's Eve 1993, by former friends Thomas Nissen and John Lotter when it was discovered "he"- at least in the eyes of his homo- and transphobic killers-was in fact a "she." Kimberly Pierce's award-winning narrative film Boys Don't Cry, starring Hilary Swank, chronicles the story, as does Gréta Olafsdôttir and Susan Muska's documentary The Brandon Teena Story. Sakia Gunn, a 15-year-old New Jersey lesbian returning from a night of partying in New York City with her girlfriend, was stabbed to death at a bus stop adjacent to Newark's busiest intersection by 29 -year-old Richard McCullogh in May 2003 after she rebuffed his sexual advances (see Smothers). 
44 / Dickinson

Development of an Aesthetic. Ed. and trans. John Willet. London: Methuen, 1964. 136-47.

Butler, Judith. Antigone's Claim: Kinship Between Life and Death. New York: Columbia UP, 2001.

- Bodies That Matter: On the Discursive Limits of "Sex." New York: Routledge, 1993.

- Excitable Speech: A Politics of the Performative. New York: Routledge, 1997.

Gender Trouble: Feminism and the Subversion of Identity. New York: Routledge, 1990.

. Precarious Life: The Powers of Mourning and Violence. New York: Verso, 2004.

Campbell, Kati. "67 Shawls." Thinking Textile. Richmond Art Gallery, Richmond. 5 December 2003-15 January 2004.

Cavell, Richard. "Histories of Forgetting: Canadian Representations of War and the Politics of Forgetting." Forthcoming in Mémoire de guerre et construction de la paix. Ed. Serge Jaumain. Bruxelles: Université Libre de Bruxelles, 2005.

Crimp, Douglas. "Mourning and Militancy." Out There: Marginalization and Contemporary Cultures. Eds. Russell Ferguson et al. Cambridge, MA: MIT Press, 1990. 233-45.

Derrida, Jacques. "By Force of Mourning." Trans. Pascale-Anne Brault and Michael Naas. Critical Inquiry 22.2 (1996): 17192.

Dolan, Jill. Geographies of Learning: Theory and Practice, Activism and Performance. Middletown, CN: Wesleyan UP, 2001.

Duncan, Ann. "Politics threaten massacre tribute." Montreal Gazette 10 Sept. 1994: I5.

Fong, Petti. "Veterans demand tenters end Victory Square protest." Vancouver Sun 17 July 2003: B3.

Fraser, Keith. "AIDS wall's site at issue." Vancouver Province 1 Dec. 1997: A2.

Freud, Sigmund. "The Ego and the Id." The Standard Edition of the Complete Psychological Works of Sigmund Freud. Vol. 19. Trans and ed. James Strachey. London: Hogarth, 1961. 12-66.

- "Mourning and Melancholia." The Standard Edition. vol. 14, 1957. 243-58.

Fuchs, Elinor. The Death of Character: Perspectives on Theater after Modernism. Bloomington: Indiana UP, 1996. 
Gillis, Margie, perf. Landscape. Chor. Christopher Gillis. Vancouver Playhouse, Vancouver. 17 March 1994.

- perf. Torn Roots, Broken Branches. Chor. Margie Gillis. Vancouver Playhouse, Vancouver. 17 March 1994.

Hirsch, Marianne. Family Frames: Photography, Narrative and Postmemory. Cambridge, MA: Harvard UP, 1997.

Huyssen, Andreas. Present Pasts: Urban Palimpsests and the Politics of Memory. Stanford: Stanford UP, 2003.

-Twilight Memories: Marking Time in a Culture of Amnesia. New York: Routledge, 1995.

Joyce, Greg. "Pickton hearing adjourned until June 30." Vancouver Sun 24 April 2003: B4.

Kelley, Caffyn. "Creating Memory, Contesting History." Matriart 5 (1995): 6-11.

Kaufman, Moisés, and members of Tectonic Theater Project. The Laramie Project. New York: Vintage, 2001.

Kushner, Tony. Angels in America, Part One: Millennium Approaches. New York: Theatre Communications Group, 1993. . "Notes about Political Theater." Kenyon Review 19 (1997): 19-34.

Lacan, Jacques. The Seminar of Jacques Lacan, Book VII: The Ethics of Psychoanalysis, 1959-60. Ed. Jacques-Alain Miller. Trans. Dennis Porter. New York: Norton, 1992.

The Laramie Project. Dir. Moisés Kaufman. HBO Films, 2002.

Lautens, Trevor. "Monument against too many." Vancouver Sun 24 June 1993: A13.

McNally, Terrence. Corpus Christi: A Play. New York: Grove, 1998. "Nazi Persecution of Homosexuals, 1933-1945." Special exhibit. United States Holocaust Memorial Museum. Washington, D.C. $<$ www.ushmm.org/museum/exhibit/online/hsx/>

Nora, Pierre, ed. Les Lieux de mémoire. Paris: Gallimard, 1997. 3 vols.

O’Connor, Sinéad. "I am Stretched On Your Grave." By Phillip King and F. O'Connor. Arranged by Sinéad O'Connor et al. I Do Not Want What I Haven't Got. Chrysalis, 1990.

Paragraph 175. Dir. Rob Epstein and Jeffrey Friedman. New Yorker Films, 1999.

Phelan, Peggy. Mourning Sex: Performing Public Memories. New York: Routledge, 1997. 
Rubin, Gayle. "The Traffic in Women: 'The Political Economy' of Sex." Toward an Anthropology of Women. Ed. Rayna R. Reiter. New York: Monthly Review Press, 1975. 157-210.

Santayana, George. "To W.P.” Sonnets and Other Verses. New York: Stone and Kimball, 1896. 60-63.

"Second youth connected to Webster beating sentenced to three years." Vancouver Sun 22 April 2004: B2.

Simon, Roger I., Sharon Rosenberg, and Claudia Eppert, eds. Between Hope and Despair: Pedagogy and the Remembrance of Historical Trauma. Lanham, MD: Rowman and Littlefield, 2000.

Smothers, Ronald. "Man arrested in the killing of a teenager in Newark." New York Times 15 May 2003: B4.

Sturken, Marita. Tangled Memories: The Vietnam War, the AIDS Epidemic, and the Politics of Remembering. Berkeley: $U$ of California P, 1997.

Vancouver AIDS Memorial: A British Columbia Landmark of Hope and Courage. < www.aidsmemorial.ca>

"Vancouver's legacy of horror, shame." Toronto Star 13 Jan. 2003: A6.

Vogel, Paula. The Baltimore Waltz. In Women Playwrights: The Best Plays of 1992. Eds. Robyn Goodman and Marisa Smith. Newbury, VT: Smith and Kraus, 1993. 99-132.

Wittig, Monique. The Straight Mind and Other Essays. Boston: Beacon Press, 1992.

Wypijewski, JoAnn. “A Boy's Life.” Harper's Magazine September 1999: 61-74.

Zacharias, Yvonne. "Gays demand action in wake of brutal killing." Victoria Times-Colonist 19 Nov. 2001: A12. 